\title{
Characteristics of menstrual disorders
}

\author{
Charakterystyka zaburzeń miesiączkowania
}

\section{Hanna Ruszkowska', Magdalena Lewicka², Magdalena Sulima², Grzegorz Bakalczuk², Anna Taracha ${ }^{3}$, Artur Wdowiak ${ }^{3}$}

'A graduate of Obstetrics, Faculty of Health Sciences, Medical University, Lublin, Poland
2Department of Obstetrics, Gynaecology and Obstetric-Gynaecological Nursing, Faculty of Health Sciences, Medical University of Lublin, Poland
'Diagnostic Techniques Unit, Medical University of Lublin, Poland

\author{
CORRESPONDING AUTHOR: \\ Magdalena Lewicka \\ Department of Obstetrics, Gynaecology and Obstetric-Gynaecological Nursing, \\ Faculty of Health Sciences, Medical University of Lublin, Poland \\ Chodźki 7, 20-093 Lublin \\ e-mail: m.lewicka@umlub.pl
}

\section{STRESZCZENIE CHARAKUERYSTYKA ZABURZEN' MIESIACGLOWANIA}

Wprowadzenie. Zaburzenia miesiączkowania występują, gdy pojawiają się nieprawidłowości dotyczące: rytmu krwawień, obfitości krwawień lub gdy występują dodatkowe krwawienia w cyklu. W artykule opisane zostały: hipogonadyzm hipogonadotropowy, zaburzenia osi podwzgórzowo-przysadkowej, niewydolność jajników, wady wrodzone narządu rodnego, hiperprolaktynemia, zespoły genetyczne, guzy okolicy podwzgórzowo-przysadkowej oraz zaburzenia niesklasyfikowane przez Światową Organizację Zdrowia.

Cel. Analiza aktualnego piśmiennictwa na temat zaburzeń miesiączkowania, usystematyzowana na podstawie klasyfikacji opublikowanej przez Światową Organizację Zdrowia.

Podsumowanie. Istotne jest, aby personel medyczny sprawujący opiekę nad kobietą w różnym okresie życia, posiadał rzetelną wiedzę nie tylko na temat fizjologii, ale również zaburzeń miesiączkowania. Pozwoli to na wczesne rozpoznanie objawów, wczesną diagnostykę i podjęcie leczenia w optymalnie krótkim czasie.

Słowa kluczowe: miesiączka, cykl miesiączkowy, zaburzenia miesiączkowania, przyczyny

ABSTRACT

\section{CHARACTERISTICS OF MENSTRUAL DISORDERS}

Introduction. The structure was based on the World Health Organisation classification. The article includes description of main causes, diagnostics and treatment of menstrual disorders. Menstrual disorder is an abnormal condition in woman's menstrual cycle. There are disorders of ovulation, cycle length, blood flow and others. The article reviews hypogonadotropic hypogonadism, disorders of hypothalamic pituitary axis, ovarian insufficiency, congenital malformations, hyperprolactinaemia, genetic syndromes, pituitary gland tumours and unclassified disorders like premenstrual syndrome and dysmenorrhoea.

Aim. Analysis of current literature with the focus on the systematisation of menstrual disorders.

Conclusion. It is crucial for medical practitioners, who take care of a female patient, to have reliable knowledge of not only physiology, but also menstrual disorders. It will allow an early recognition of the symptoms, proper diagnosis and treatment in the optimal time.

Key words: menstruation, menstrual cycle, menstrual disorders, causes

\section{INTRODUCTION}

Menstrual disorders include: ovulation disorders, abnormalities in cycle regularity, changes in menstrual bleeding and pathological bleedings during a menstrual cycle. As many as $75 \%$ of women suffer from menstrual disorders $[1,2,3]$. In the article the authors focused on classification and clarification of causes and specifics of menstrual disorders. Since 1976 there has been a classification of menstrual disorders created by the World Health
Organisation. According to this classification, disorders are divided into seven groups based on the cause of the disorder [4]. Each group is thoroughly described in the article, including causes, effects, complications and treatment. The epidemiology of the syndromes varies from very rare such as Kallman Syndrome to common polycystic ovary syndrome. It is probable, that most medical practitioners will encounter a patient with menstrual disorder during their practice. 
The groups are described as follows: hypogonadotropic hypogonadism, disorders of hypothalamic pituitary axis, primary and secondary ovarian insufficiency, malformations and acquired defects of uterus and birth canal, hyperprolactinaemia, adenomas of the anterior pituitary gland and other non-classified menstrual disorders.

\section{GROUP}

The first group includes patients with no menstruation (usually secondary) caused by hypogonadotropic hypogonadism. This disorder is connected with insufficient secretion of GnRH by hypothalamus or with a malfunction of anterior pituitary gland causing insufficient production or secretion of gonadotropins. Amongst disorders causing primary amenorrhoea the most common are physiological or constitutional delay of puberty. It can be also caused by insufficient somatic development due to delayed reactivation of $\mathrm{GnRH}$ pulses. In patients with physiological delay of puberty, the level of GnRH is corresponding with the physiological development, but it is too low according to age. Kallmann Syndrome is a condition characterized by insufficient secretion of GnRH pulses, which can cause deficiency of LH and FSH levels. Low concentration of gonadoliberin can be related to genetic and development abnormalities, vascular defects, tumours, inflammatory process or trauma. Kallmann Syndrome manifests in primary amenorrhea. Hyposmia, reduced sense of smell, is characteristic for this syndrome. Patients with this syndrome have height respective to age, in comparison to the ones with physiological delay of puberty $[5,6]$.

Secondary hypogonadotropic hypogonadism caused by long-lasting stress, intense physical exercises, psychiatric disease (anorexia nervosa), malnutrition or drug addiction is more frequent in female patients. These factors can lead to inhibition of hormonal function of hypothalamus and anterior pituitary gland. It can cause delay of puberty in girls while mature woman can experience secondary amenorrhea together with involution of secondary and tertiary sexual characteristic $[7,8]$.

Hypogonadotropic hypogonadism diagnostics is based on evaluation of secondary and tertiary sexual characteristic and smell study. Medical history should be taken including information on: physical activity, body mass changes, diet, stress level, drugs. BMI and body fat percentage should be counted. In laboratory tests levels of: FSH, LH, E2, PRL should be marked. In hypogonadotropic hypogonadism levels of FSH, LH, E2 can be very low or on a limit of determination. In the test with intravenous administration of GnRH, the most common observation is reduced reserve of $\mathrm{LH}$ or prepubertal response. Test with clomifene is usually negative. It is necessary to perform CT or MRI to check for any changes in central nervous system, especially in case of symptoms such as: galactorrhoea, changes in the field of vision, headaches. Estrogens, progestagens, FSH, LH and GnRH are used in treatment of the condition. The plan of the treatment depends on the therapeutic goal. Treatment of hypogonadism resulting from intense workout, malnutrition or strong long-term stress need to be based on elimination of these factors, accordingly: change of lifestyle, well-balanced diet and elimination of stressful factors. Supplementation of vitamin D and calcium is recommended. Serious illnesses such as, anorexia or bulimia, require psychiatric treatment $[4,5,9]$.

\section{GROUP}

The second group includes disorders of hypothalamic pituitary axis. This group states $80 \%$ of all female patients with menstrual disorders $[9,10]$. Function of the axis remains correct with secretory rhythm disorder. Most of the patients have polycystic ovary syndrome (PCOS). This syndrome applies to $10-15 \%$ of women in the reproductive period. Although PCOS is the most common endocrinopathy, its causes are not known. A constant feature of the syndrome is a stop of follicular development in a stadium of antral follicle, just before selection. Lack of recruitment of dominant follicle results in concentration of many antral follicles (size of 4-7 mm) in an ovary. Thecal cells of these follicles produce excessive amount of androgens. Characteristic for PCOS are: chronic lack of ovulation, hypomenorrhoea, amenorrhoea, ovarian pathologies, difficulty getting pregnant, hyperandrogenism, obesity and insulin resistance $[10,11]$. Main diagnostic criteria, according to the National Institutes of Health and of Child Health and Human Development are: oligoovulation, clinically or biochemically confirmed androgen excess. Other causes of no ovulation (hyperprolactinemia, hypogonadic and hypergonadic disorders, thyroid disease) and hyperandrogenism (AOAH, Cushing syndrome, adrenal or ovarian tumours) should be excluded. Secondary criteria include less frequent symptoms: insulin resistance, elevated ratio of $\mathrm{LH}$ to FSH, hirsutism during menarche, transient lack of ovulation connected to hyperandrogenism, characteristic picture of ovaries in an ultrasound examination, obesity. The goal of PCOS therapy is regulation of menstrual bleeding, reduction of symptoms of hyperandrogenism (excess hair, alopecia androgenetica, acne), body mass reduction [12].

Corpus luteum insufficiency is also included in the second group according to the WHO. The disorder characterises with insufficient progesterone secretion by corpus luteum. It prevents proper development of endometrium and implantation of embryo. It can be a reason of infertility and miscarriage. Corpus luteum insufficiency is diagnosed in 3-20\% of infertile women and $5-60 \%$ of patients with recurring miscarriage. Abnormal secretion of $\mathrm{GnRH}$ pulses resulting in abnormal levels of $\mathrm{LH}, \mathrm{FSH}$, estradiol and progesterone is one of the causes of corpus luteum insufficiency. Amongst other causes there are: thyroid diseases, prolactin secretion abnormalities, endometriosis, PCOS, obesity, stress, reduced ovarian reserve, increased secretion of beta-endorphin, lactation, post transplantation state. Symptoms of CLI are short luteal phase and premenstrual bleedings. Evaluation of function of corpus luteum is done by measuring core body temperature and by determination of progesterone level in blood in luteal phase. In treatment of CLI, progesterone or progesterone with estrogens and hCG supplementation in the premenstrual phase is used. Additionally, induction of ovulation with gonadotropins or clomifene can be done [6]. 


\section{GROUP}

In the third group we can distinguish primary and secondary ovarian insufficiency. Primary ovarian insufficiency can be seen in patients with: Turner Syndrome (45X0), Sweyer Syndrome (46XY), pure gonadal dysgenesis (46XX), women with deletion of chromosome X. It is usually diagnosed in female patients without symptoms of the disease. Some of the diseases mentioned before are diagnosed in childhood, because of characteristic body features. Characteristic for Turner Syndrome are: short stature (less than $150 \mathrm{~cm}$ ), short webbed neck, lopsided elbows, specific chest structure. Gonads are fibers of connective tissue without any follicles. Patients do not menstruate, have small uterus and narrow vagina. Additionally, there is a risk of cardio-vascular disorders and lymphatic edema. Treatment is a hormone replacement therapy and administration of growth hormone, which enables development of sex characteristics and body stature. Patients with Turner Syndrome with mosaicism can observe spontaneous menstrual bleeding [13]. Sweyer Syndrome is characterised by lack of sexual characteristics development with correct body stature. Ovarian follicles in $20-30 \%$ of women with this syndrome develop cancer, so gonads should be laparoscopically removed and the procedure should be followed by a hormone replacement therapy.

Secondary ovarian insufficiency can be caused by premature ovarian failure, as a result of chemo or radiotherapy, or after bilateral removal of gonads. In these patients we can observe symptoms characteristic for menopause. Premature ovarian failure is a secondary amenorrhoea observed before the age of 40. Causes of POF are not well investigated but amongst the most common reasons there are: autoimmune and genetic factors, infections, as a result of chemo or radiotherapy or enzymatic disorders such as galactosemia. In the range of modifiable factors we can mention smoking cigarettes, which accelerates process of menopause. POF has two forms: follicular and afollicular. In the afollicular type, depletion of follicles is caused by small number of follicles in an ovary. In a follicular type, there are plenty of follicles in different stages. This form is also known as gonadotropin insensitivity syndrome. Diagnosis is made on the basis of: secondary amenorrhoea for at least 4 months, in laboratory test in two samples taken within a month apart if the concentration of FSH in blood is higher than $40 \mathrm{jm} / \mathrm{l}$. Menstruation cycle may vary. In many patients lack of menstruation is sudden and happen after regular menstrual cycles. In other patients amenorrhoea is preceded by many irregular cycles. It can also be seen after getting off hormonal oral contraceptives or after pregnancy. If possible, treatment of the causes is recommended, for example in patients with celiac disease, introducing a gluten-free diet. Replacement therapy is based on using hormone replacement therapy and enables to minimize the symptoms. There are cases where immunomodulatory therapy, which is administration of high doses of steroids or intravenous immunoglobulins, was effective. There are studies on beneficial effect of melatonin and DHEA supplementation on women with premature menopause $[4,14]$.

\section{GROUP}

The fourth group includes congenital malformations and acquired defects of uterus and birth canal. We can mention menstrual disorders caused by birth defects of uterus and vagina or secondary uterine atresia (Asherman Syndrome). Birth defects are divided into: gynatresiae, septa, duplications, organa rudimentaria, hypoplasias and agenesis or aplasia $[6,15,16]$.

Congenital malformations can manifest by menstrual disorders, regular abdominal pain, infertility, recurrent miscarriage, premature birth, childbirth complications. Primary amenorrhoea occurs in patients with no uterus, or with atresia of birth canal. Early diagnosis is crucial, best made soon after menarche. Accumulation of menstrual blood in vagina in gynatresias can manifest with recurrent abdominal pain. Lack of menstruation is observed $[6,17]$. Diagnosis is made based on physical and gynaecological examination, followed by ultrasound examination. In some cases there is a need to perform MRI or gynaecological examination with sedation. Malformations are treated surgically. Overgrowth of the virgin membrane is treated by an $\mathrm{x}$-shape incision and removal of excessive tissue. Treatment of agenesis of cervix depends on the type of the condition and can require hysterectomy, which is a very serious surgery. Patients with a unicornuate uterus with a functioning endometrium with no communication to uterine cavity require surgery in early puberty. Lack of treatment can cause haematometra and pyometra $[6,16,17]$.

Congenital aplasia of uterus and vagina is characteristic for Mayer-Rokitansky-Küster-Hauser Syndrome (Mullerian agenesis). It is estimated that it occurs 1 in 5000 female births. While there are no structures developing from mullerian duct, ovaries have proper anatomy and physiology. Patients develop secondary and tertiary sexual characteristics but are infertile due to primary amenorrhoea and malformations of uterus and vagina [6].

Asherman's Syndrome is an acquired condition characterized by adhesions and fibrosis of endometrium and in result, uterine or cervical atresia. The most common cause of the disorder is dilation and curettage of uterine cavity after a miscarriage or delivery. Others are: caesarean section, hysteroscopy, pelvic inflammation or even genital tuberculosis. Treatment is based on removal of adhesions during hysteroscopy. It can be accompanied by hormonal treatment [4].

\section{V and VI GROUP}

Hyperprolactinaemia is distinguished in the groups. It is an abnormal level of prolactin in blood and is defined by over $25 \mu \mathrm{g} / \mathrm{L}$. It is a symptom, not a disease and can indicate an organic or functional disorder of hypothalamic pituitary axis. Over one third of cases of hyperprolactinaemia is caused by pituitary microadenomas (prolactinoma). Patients with prolactinoma are classified in the fifth group of menstrual disorders. In the sixth group there are patients with reactive (functional) hyperprolactinaemia. Some of the causes of the reactive disorder are: kidney failure, hypothyroidism, acromegaly, hepatic cirrhosis, use of antidepressants, metoclopramide, methylodopa, 
werpamil, oral contraception. It can occur in drug-addicted patients, after major trauma or surgery of thorax $[6,9,12]$.

Elevated levels of prolactin can remain symptomatically silent or manifest as hypogonadism, infertility, galactorrhoea or amenorrhoea. Approximately $15 \%$ of patients with amenorrhoea with no galactorrhoea have hyperprolactinaemia. While two third of patients with amenorrhoea with simultaneous galactorrhoea have hyperprolactinaemia, and one third of them have a prolactinoma. Main reason of lack of ovulation is an inhibition of $\mathrm{GnRH}$ pulses caused by elevated level of prolactin. It also influences follicles and bonding of follicle stimulating hormone. It inhibits 17alfa-estradiol secretion and lowers progesterone levels in luteal follicles. Galactorrhoea with physiological menstruation can also indicate hyperprolactinaemia. Although, almost half of the women in such cases, have normal prolactin blood level [6]. For diagnosis, metoclopramide test is used. Administration of metoclopramide causes elevation of prolactin by from 5 to 10 times in healthy women. There is no prolactin peak observed in patients with prolactinoma. If the concentration of prolactin is higher than $250 \mu \mathrm{g} / \mathrm{L}$, it can indicate a macroadenoma. In such case MRI examination is required $[9,18]$.

In treatment, drugs from dopamine agonist group are used. Treatment causes regression of adenoma, reduction of prolactin level in blood, restoration of gonadal function. Indication for the treatment is secondary amenorrhoea [12].

\section{GROUP}

In this group, the WHO classified other adenomas of the anterior pituitary gland. Amongst other disorders there are: post-traumatic failures, autoimmune and inflammatory process, iatrogenic causes, brain tumours. The most common tumours of thalamic pituitary region are craniopharyngioma, meningioma, malignant germ cell tumours. They affect production and secretion of $\mathrm{GnRH}$ and anterior pituitary hormones. They cause a range of symptoms depending on the function of hormones. Other symptoms are changes in the field of vision, diabetes insipidus, secondary obesity, neuropsychiatric disorders. Hypogonadotropic hypogonadism can be caused by: leukaemia, sarcoidosis, lymphoma, granulomatosis with polyangiitis, hemochromatosis, histiocytosis. Diagnostics is based on imaging of the brain. Treatment depends on oncologists and surgeons. Patients after surgical treatment require hormone replacement therapy $[6,9]$.

\section{Other non-classified menstrual disorders}

Amongst disorders not included in the classification prepared by the $\mathrm{WHO}$, premenstrual syndrome (PMS) and dysmenorrhea (painful periods) have to be mentioned.

Premenstrual syndrome refers to physical and emotional syndromes that occur after ovulation and stop with the beginning of menstruation. Most common psychological symptoms are: exasperation, nervousness, lack of energy, insomnia, mood-swings, disturbed concentration. Somatic manifestation can present as: headaches, dizziness, breast pain and oversensitivity, increased appetite, muscle pains, acne. There are three stages of PMS depending on its intensity and effect on the woman. Stage one does not interfere with woman's activity. In stage two (mild) there can be some difficulties with everyday activity and reaction to stress stimulation. Stage three (serious) of PMS prevents women from everyday activity and exclude from social life. Causes of its occurrence are not defined, but it is known that hormonal changes have a huge role in the process. Increase of PGE and E2 level influences expression of neurotransmitters such as serotonin and gammaaminobutyric acid. Secretion of this neurotransmitters increases in the postovulation phase and is said to elevate the mood. Research claim that approx. $40 \%$ of women with PMS have low concentration of endorphins and higher activity of pseudocholinesterase [12].

Dysmenorrhoea is an increased pain in the lower abdomen during or before menstruation. It can occur since the beginning of ovulation cycles ( 6 to 12 weeks after menarche) or at any point after painless menstrual cycle. Primary dysmenorrhoea is diagnosed in women who do not have organic causes such as: endometriosis, pelvic inflammations, uterine fibroids, congenital malformations, cervical pathology. Pain is usually connected with cramps in lower abdomen and can radiate to back on either side. Pain last one to three days and can begin before bleeding. Other symptoms are: diarrhea, nausea, dizziness, hypersensitivity, fatigue. It is estimated that this condition can affect $40-60 \%$ of women, mostly in the young age. Diagnostic base is a medical history, physical and gynaecological examination, ultrasound examination. The diagnosis can be done after elimination of all possible organic causes. Treatment of the syndrome is pharmacological: use of inhibitors of prostaglandin synthetase (ibuprofen, naproxen) and oral contraception. Supplementation of vitamin $\mathrm{B}, \mathrm{E}$ and magnesium can be introduced $[4,9,19,20]$.

Secondary dysmenorrhoea is connected with pathological processes in pelvic cavity, such as: endometriosis, adenomiosis, uterine fibroids, endometrial polyp and others. In comparison to primary dysmenorrhoea, it starts between the ages of thirty and forty. Symptoms like irregular bleedings and dyspareunia can accompany. Diagnosis is made like in the primary type. Treatment is dependant on the organic cause.

\section{CONCLUSION}

A significant part of a woman's life, since menarche to menopause, is the time of menstrual cycles. The education of women in the field of gynaecological disorders, including the ones connected to menstruation, should be a primary task of medical personnel. It is therefore important for medical practitioners to have reliable knowledge, not only on physiology but also on a wide topic of menstrual disorders. It will allow an early recognition of the symptoms, proper diagnosis and treatment in the optimal time. 


\section{REFERENCES}

1. Monist M, Bartuzi A, Olcha P, i wsp. Wskazania ginekologiczne do hospitalizacji dziewczynek i młodych kobiet - postępowanie w wybranych przypadkach klinicznych. Ginekologia Polska. 2015; 86: 53-61.

2. Rekomendacje PTG dotyczące postępowania w zaburzeniach miesiączkowania u dziewcząt. Ginekologia po Dyplomie. Wyd.Spec. 2009; 09: 128-132.

3. Monawara B, Sumit D, Sharma HK. Menstrual disorders: causes and natural remedies. Journal of Farmaceutical, Chemical and Biological Sciences. 2016; 4(2): 307-320.

4. Podfigurna-Stopa A, Męczekalski B. Zaburzenia miesiączkowania. [w:] Bręborowicz GH. Położnictwo i Ginekologia. Warszawa: Wydawnictwo Lekarskie PZWL; 2016, s. 101-104.

5. Zawadzka A. Zaburzenia miesiączkowania w okresie dojrzewania. Nowa Klinika. 2012; 19 (5): 5057-5061.

6. Santoro NF, Neal-Perry G. Amenorrhea - A Case-Based Clinical Guide. [w:] Contemporary Endocrinology. Human Press; 2010, s. 35-44, 55-65, 83-100.

7. Sultan C. red. Pediatric and adolescent gynecology. Evidence-based clinical practice. 2nd, revised and extender editio. Endocr Dev. Basel, Karger. 2012; 22: 160-170.

8. Kozikowska B, Urban J, Kukowska D. Wpływ odchudzania na przebieg cyklu płciowego u dziewcząt. Zeszyty Naukowe, nr 50: Otyłość jako rosnący problem społeczeństwa. Łomża: Wydawnictwo Wyższej Szkoły Agrobiznesu w Łomży; 2013, s. 53-66.

9. Skałba P. Diagnostyka i leczenie zaburzeń endokrynologicznych w ginekologii. Kraków: Medycyna Praktyczna; 2014, s. 107-140.

10. Putowski L, Semczuk A. Kryteria diagnostyczne owulacji. [w:] Domżał - Drzewicka $\mathrm{R}$, Gałęziowska E. red. Nowoczesne metody rozpoznawania płodności. Wybrane zagadnienia. Lublin: Makmed; 2007, s. 21-26.
11. Katulski K, Czyżyk A, Męczekalski B. Hiperandrogenizacja i zespół policystycznych jajników. [w:] Bręborowicz GH. Położnictwo i Ginekologia. Warszawa: Wydawnictwo Lekarskie PZWL; 2016, s. 121-128.

12. Sobieszczańska-Jabłońska A, Salata I. Choroby tarczycy a zaburzenia miesiączkowania. Nowa Klinika. 2010; 17(2): 255-256.

13. Sowińska-Przepiera E, Andrysiak-Mamos E, Jarząbek-Bielecka G, i wsp. Pierwotna i wtórna niewydolność jajników w okresie dojrzewania. Klinika Pediatryczna. 2011; 19(5): 5077-5081.

14. Jankowska K. Przedwczesne wygasanie czynności jajników. Postępy Nauk Medycznych. 2014; (XXVII)12: 860-864.

15. Friebe Z, Kapczuk K. Wady wrodzone żeńskich narządów płciowych. [w:] Bręborowicz GH. Położnictwo i Ginekologia. Warszawa: Wydawnictwo Lekarskie PZWL; 2016, s. 33-40.

16. Rechberger T, Kulik-Rechberger B. Anomalie rozwojowe narządu rodnego etiopatogeneza, diagnostyka i leczenie. Forum Medycyny Rodzinnej. 2011; 5(2): 130-136.

17. Rechberger T, Kulik-Rechberger B. Wady wrodzone układu moczowo - płciowego u kobiet - diagnostyka i postępowanie. Ginekologia Polska. 2011; 82: 137-145.

18. Czyżyk A, Męczekalski B. Podstawy diagnostyki w endokrynologii ginekologicznej. [w:] Bręborowicz GH. Położnictwo i Ginekologia. Warszawa: Wydawnictwo Lekarskie PZWL; 2016, s. 95-101.

19. Mrugacz G, Grygoruk C, Sieczyński P, i wsp. Etiopatogeneza zespołu bolesnego miesiączkowania. Developmental Period Medicine. 2013; XVII(1): 85-89.

20. Teul I, Kliś K, Jarząbek K, i wsp. Częstość występowania oraz czynniki skorelowane z bólem miesiączkowym u zdrowych studentek. Roczniki Pomorskiej Akademii Medycznej w Szczecinie. 2014; 60(2): 9-94.

Manuscript received: 05.10.2017

Manuscript accepted: 15.01.2018

Translation: Anna Taracha 